\title{
Exploring the Digital Game-Based Elements in Mathematics Education: A Meta-Analysis Review
}

\author{
Hemanathan Harikrishnan ${ }^{1, *}$, Noor Dayana Abd Halim¹, Jamalludin Harun', Shalini Arjunan² \\ ${ }^{1}$ School of Education, Faculty of Social Sciences and Humanities, Universiti Teknologi Malaysia, Malaysia \\ ${ }^{2}$ Faculty of Languages and Linguistics, Universiti Teknologi Malaysia, Malaysia
}

Received July 9, 2019; Revised September 9, 2019; Accepted September 16, 2019

Copyright $\bigcirc 2019$ by authors, all rights reserved. Authors agree that this article remains permanently open access under the terms of the Creative Commons Attribution License 4.0 International License

\begin{abstract}
This paper is an attempt to analyze critically the existing empirical studies of digital game-based learning courseware in Mathematics education. The major purpose of this meta-analysis is to identify effective game-based element to customize an engaging learning courseware. The meta-analysis was done focusing on Mathematical subjects to understand how digital game-based learning affects the learners' knowledge in mastering new Mathematical concepts. This article review is comprised of 17 empirical studies which were constructed on different framework of game-based elements. The findings revealed that there are twelve essential game-based elements namely fun, play, rules, goals, interaction, outcome, adaptive, winning conflict, problem solving, interaction and representation which are essential to create sense of engaging when adapting DGBL Courseware in Mathematics' education. The systemic review enables the researcher to design a game model for Mathematics learning.
\end{abstract}

Keywords Digital Game Based Learning, Game Based Elements, Engagements

\section{Introduction}

Globalization in education brings changes in teaching and learning practices in the classroom. These changes slowly bring crashes into conventional educational practices such as teacher-centered learning, memorization and task-based approaches (Rushton, Hadley, \& Stewart, 2016). The overcrowded curriculum with conventional classroom settings is not conducive in the slow learners' learning process (McLaren, Adams, Mayer, \& Forlizzi, 2017). Slow learners are students who lack the ability to interpret, process and understand new skills in learning (Vasudevan, 2017). Thus, through the use of Information and Communication Technology (ICT), educational technology has evolved throughout the years and invented many new strategies to facilitate teaching and learning among slow learners (Zielezinski \& Darling-Hammond, 2018). Remedial classrooms are specially designed for slow learners who fail to acquire specific skill of learning (Lim \& Leong, 2017). On the other hand, remedial teachers are also exposed to the usage of Digital Game-Based Learning (DGBL) to overcome difficulties in teaching the slow learners (Furió, González-Gancedo, Juan, Seguí, \& Rando, 2013). The studies from Tsia (2016) indicate that learners faced greater challenges in acquiring Mathematics' rather than linguistic subjects. Learners experience frustration and struggle with understanding simple calculation in Mathematics. Their lack of ability to interpret the content of Mathematics into application question discourages them from mastering computational skills. Indirectly, this causes the learners to disengage during learning mathematics'. In order to develop engagement in learners, Karimi \& Lim, (2010) agreed that the integration of DGBL is an effective method of learning in classroom. Therefore, the main focus of this article is to review selected empirical studies of past researches to identify appropriate game-based elements in specified frameworks in order to customize a DGBL in Mathematics.

\section{Game Based Learning in Education}

Game-based learning is a type of teaching approach practiced in the classroom to foster student's understanding of learning topics (Abdul Jabbar \& Felicia, 2015). Game-Based learning methods used in the classroom can be in the form of physical or digital settings (Yeh, Hung, \& Hsu, 2017). In a physical setting, the teachers utilize existing physical game-based materials, by incorporating game elements, as it integrates fun and excitement into 
learning (Alaswad \& Nadolny, 2015). Usually, the physical game-based learning practiced in school includes hide-and-seek, ball games, card and board games, playground games and role play games, which can stimulate learning among slow learners (Hwang, $\mathrm{Wu}, \&$ Chen, 2012).

Digital Game-based learning is learning with use of electronic devices as a part of teaching and learning purpose (Lim \& Leong, 2017). Game-based learning is also known as media-based learning approach; in school settings, learners use laptop, notebook and computer as a source of learning materials (Khamparia \& Pandey, 2018). The above scholars believe that the usage of such media in game-based learning build a meaningful environment for learners to understand complicated, contextual knowledge in an easy way (Murphy, Coover, \& Owen, 1989). This is because game-based learning with adapted learning elements will support learners' understanding in specific learning area (Khamparia \& Pandey, 2018). In his work, the established scholar, Prensky (2001) defines digital game-based learning as an integration of educational content with game-based elements. The combination of educational content and game-based elements promote learners active participation in learning (Kwon, Lara, Enfield, \& Frick, 2013). Apart from that, digital games integration in classroom settings also enhances learners' creativity and raises learners' passionate involvements to construct new knowledge from learning topics (Aesaert et al., 2015). Multiple studies have been conducted in this research field, however there is a lack of empirical studies that substantiate the effectiveness of game-based elements to develop DGBL. The past studies are usually limited to the evaluation of educational games' effectiveness without the consideration of relevant learning theories and game elements (Powers, 1992).

The question that may arise here is whether there is indeed empirical research that offers evidence to confirm the effectiveness of DGBL elements in school settings. The few authors that did concentrate on these game-based elements in DGBL are designated as somewhat outdated since this is a quick evolving and emergent area, especially in the past five years. The findings from this article suggest that valuable game-based element should be incorporated in game designing and to facilitate Mathematics learning. Digital game-based settings commonly utilize computer mediated programs. For example, in DGBL, games are widely accepted in online-orientated learning, courseware-based learning and mobile learning.

\subsection{Terms of Games in Education Technology}

Game-based learning in the digitalized world uses different terminologies namely Digital Games (DG), Video Games (VG) and Serious Game (SG) (F. H. Tsai, 2018). In the educational field, Digital Games are known as intellectual games that trigger the learners to mindfully overcome the challenges in the learning context (Connor \& Domingo, 2017). These challenges are usually in the form of puzzles or quizzes and could be completed by learners through adapting specific rules (Khamparia \& Pandey, 2018). This allows learners to move to a further level in the games. In education, especially, the Digital Games are widely incorporated with interactive game mechanics such as rules, goal, and feedback (Alaswad \& Nadolny, 2015). These elements enable players to monitor their progress in the subject learning (Khamparia \& Pandey, 2018). Prensky (2001) stated that engaging game-based elements does not just embed game mechanics, but also create a sense of engagement through entertainment activities in the game courseware (Marvel, 2017).

Similarly, Video Games share the characteristics of Digital Games (Ortiz, Bowers, \& Cannon-Bowers, 2015). However, Video Games are mainly designed for entertainment purposes only (Tobias, Fletcher, \& Wind, 2014). Commonly, Video Games are played in electronic devices such as computer monitors or TV screen devices (Tobias et al., 2014). In the findings of Tobias et al., (2014), it is stated that Video Games are designed to fulfill the need of marketing in the industrial world. Hence, most game developers in the industrial world produce games by placing profit as a main agenda (Kumar Bhowmik et al., 2018).Therefore, learning theories with appropriate game based element is important to customized DGBL Courseware.

In addition, next is the Serious Game, which is also known as educational games (Jong et al., 2017). Serious Game has a specific purpose but lack the entertainment aspects. Serious Game in the educational field includes pedagogical theories and learning strategies (McLaren et al., 2017). However, the Serious Games fail to incorporate entertainment elements to trigger learners' passionate involvement in learning. The main purpose of serious games in education is to develop individual soft skills, for instance, knowledge, experiences and technical skills (Ke, 2013). The above term is used by educationist to describe game based courseware in education.

\subsection{Designing Games for Education}

Designing games for education is an extensive process (Adamo \& Dib, 2013). First of all, designers have to identify the instructional design of their learning courseware. For that purpose, educationists have to adapt the correct instructional approach, relevant learning theories and game-based elements to enhance learners' understanding in the subject matter (McLaren et al., 2017).

\subsubsection{Game Based Design Elements for Education}

Previous studies in DGBL investigate learners' achievement in learning, leaners' motivations and their problem-solving skills (Yeh et al., 2017). However, there is a dearth of studies on integrating game-based elements to 
create engaging environment for learning (Fredricks. et al., 2011). The issues are related because the educationists are learnt to have a lack of knowledge and understanding in the importance of integrating game-based elements in DGBL (Akpinar \& Sengül, 2018). The learning games that are readily available in the market presently are focused on academic aspects, learning content, different needs of the learners, repetitive exercise, and numerous of facts (Chauhan, 2017). However, these types of learning courseware fail to support learners' engagement in education (Ke, 2013). These game designs eventually create boredom among the learners (García, 2017).

Meanwhile, the established scholars in the game-based field such as Prensky (2001), Wilson et al, (2009) and Aldrich, (2015) claimed that the integration of entertainment game-based elements promotes engagement to learners' active participation in learning (Pesare, Roselli, Corriero, \& Rossano, 2016). Fun, adaptive, play, rules, goals, interaction, interaction, conflict, problem-solving, interactive and representation are the key elements in game-based learning (Prensky, 2001). These elements in games integrate both entertainment elements and learning principles (Hamari et al., 2016). For instance, the game elements encourage players to try different ways of learning and thinking in order to master the learning topic (Lim \& Leong, 2017). Therefore, game-based elements are important and should be incorporated in DGBL courseware.

\subsubsection{Game-Based Learning Theories for Education}

Teaching and learning would be incomplete without learners' participation and involvement (Freeman et al., 2014). The DGBL with relevant game element will enhance learners' engagement. Thus, failure to integrate learning theories will cause learners' inability to develop the understanding of learning content (Kose \& Arslan, 2015). Educationists used various learning theories to facilitate learners' acquisition in subject areas (S. C. Tsai, 2011). Learning theories are focused on learners' ability to process information during learning. However, not all learning theories have positive effect on learners' achievements (Hirata, 2018). Hence, in order to customize a DGBL courseware, learners' characteristics need to be taken into consideration when determining relevant learning theories that align with the game elements (Muppudathi, 2014). There are three main theories usually adapted in teaching, namely behaviorism, cognitivism and constructivism (Karajeh, Hamtini, \& Hamdi, 2016).

Behaviorist theory in courseware explains that the learners' behavioral changes towards learning process (Schlesinger, Wang, Heights, \& Macdonald, 1987). Behaviorists defined that learning exists in the condition of rewards and targets (Jagu, Boti, \& So, 2018). The theory emphasizes on learners' reinforcement and stimulation, which creates the sense of engagement in learning (Dames, 2016). As opposed to behaviorism theory, cognitivism theory calls on learners' ability to use the mind to think creatively for problem-solving during learning activities (Adamo-Villani \& Dib, 2013). Additionally, compared to cognitivism and behaviorism theories, the constructivism learning theory is complex and comprehensive (Bano, Zowghi, Kearney, Schuck, \& Aubusson, 2018). This is because the constructivism learning theory is divided into two aspects, namely social constructivism and cognitive constructivism (Hussein, 2009). In social constructivism, the propellants state that learners construct learning through interactions, while cognitive constructivism has more to do with the assimilation of new information to existing knowledge. The researchers adopt constructivism learning principles, instead of behaviorism and cognitivism, because they argue that knowledge is actively constructed by learners until they account that the particular knowledge suits their understanding. There are three main principles focusing on constructivism theory to bring a significant learning namely knowledge, active learning and meaningful environment (Teo \& Koh, 2010). Therefore, it is safe to say that constructivism theory embeds both social and cognitive aspects, which engages learners to participate in game-based learning to construct knowledge (Dames, 2016). Educationists state that constructivism believes that the ability of learners relies on their prior knowledge (Furió et al., 2013). Hence, constructivism theory could be the ideal learning theory to be adapted in designing DGBL as DGBL supports active learning and creates meaningful environment for learners in order to construct knowledge (Theses et al., 1998). In contrast, behaviorism theory seeks for behavioral changes meanwhile cognitivism theory reports on obtaining knowledge by analytical and critical thinking. Therefore, the constructivism theory's attributes are in accordance with DGBL. DGBL enables the advancement in learners by exploring the technology to bring changes in behavioral and cognitive perspectives (Hussein, 2009). Thus, constructivism learning theory integration in learning courseware helps to create engagement in learning. The selection process of learning theories depends on learners' characteristics and their difficulties in learning.

\subsection{Research Objective}

With growing interest in DGBL, rigorous empirical evidences are needed to support the effectiveness of DGBL elements in learning Mathematics. Mathematics is a computational subject wherein learners frequently use concepts, symbols and numbers in order to solve arithmetic problems (Lim \& Leong, 2017). The existing research in Mathematics courseware have explored many variables, namely self-efficacy, self-esteem, engagement, achievements, motivation, concentration and interest (Chauhan, 2017). However, research has been unable to identify the barriers to designing a good educational game and how the designed game can be used in most effective way in the classroom (Marvel, 2017). Thus, the past studies 
failed to cover the relevant game-based elements that can engage slow learners' participation in learning (Kiili, Moeller, \& Ninaus, 2018). The aim of this study is to identify the empirical evidences of previous research in order to determine appropriate game-based elements in designing and developing an engaging DGBL in Mathematics education by calculating size effect. The findings from this study could provide valuable guidance for educators for further development of learning courseware in Mathematical field.

\section{Methodology/ Materials}

The articles involved in this study were selected systematically. A key word search was conducted in four databases namely Science Direct Journal, Web of Science, Springer and Scopus. The terms that have been used to collect the articles are, "Digital Game Based Learning", "Serious Game", "Video Game". These descriptors were derived from an initial, non-systematic exploration of the literature. The terms "(study or research)" were respectively used to focus the search on empirical research studies because the aim was to retrieve studies on the educational effectiveness of games. The articles were taken from a fixed time limit by the researcher, which is in the range of year 2015 to year 2018. Based on online databases mentioned above, a total of 142 articles, related to game-based field in Mathematics' education, were collected. Thereafter, the researcher selected 17 articles (out of the 142 articles) which were related to Mathematics education and aligned with the constructivism principles. The articles that complied with the following criterion were kept; the article describes empirical studies (quasi-experimental) that made use of a computer-based-game in Mathematical educational setting and integrates constructivism theory and game-based elements. The 17 articles were then studied thoroughly to identify the respective game-based elements that were used to propose DGBL. Overlaps were immediately excluded and all abstracts were read through. The researcher excluded the articles that were irrelevant to current studies; whereby studies that discussed the general framework, collected data based on qualitative analysis, and had no constructivism elements principles or systematic review of DGBL were removed. Based on these filtered articles, only 17 articles could be utilized for this study. Table 1 shows an overview of the collected data from the online databases.

Table 1. Overview of Collected data from various of online database

\begin{tabular}{|c|c|c|}
\hline $\begin{array}{c}\text { Online } \\
\text { Database } \\
\text { Source }\end{array}$ & $\begin{array}{c}\text { Articles related to Game } \\
\text { based learning in } \\
\text { Mathematics' }\end{array}$ & $\begin{array}{c}\text { Articles with } \\
\text { empirical } \\
\text { studies }\end{array}$ \\
\hline Web of Science & 32 & 5 \\
\hline Science Direct & 77 & 9 \\
\hline Springer & 19 & 1 \\
\hline Scopus & 14 & 2 \\
\hline
\end{tabular}

Table 1 shows the articles that reported on studies have empirical findings. All these studies were adapted from various frameworks of game-based elements, which were constructed by five main scholars namely Alessi and Trollip, 2001; Prensky, 2001; Wilson et al., 2009; Vogel et al., 2006 and Aldrich, 2005. Table 2 illustrates the game elements and the respective scholars who had constructed these elements of design and development in game-based learning. Table 2 also clarifies the research domain and number of articles that correspond to each scholar and game-based elements.

Table 2. Scholars and invented Game Based Elements

\begin{tabular}{|l|l|c|c|}
\hline \multicolumn{1}{|c|}{ Scholars } & \multicolumn{1}{|c|}{ Game Based Elements } & Research Domain & $\begin{array}{c}\text { Numbers of } \\
\text { Articles }\end{array}$ \\
\hline $\begin{array}{l}\text { Alessi and } \\
\text { Trollip, 2001 }\end{array}$ & $\begin{array}{l}\text { Feedback, Multitasking, making decision, Strategy, Chance, Conflict and } \\
\text { problem solving }\end{array}$ & Cognitive & 2 \\
\hline Prensky, 2001 & $\begin{array}{l}\text { Fun, Play, Rules, Goals, Interaction, Interactive, Outcome, Winning, } \\
\text { Conflict, Problem Solving, Adaptive, Interaction, and Representation }\end{array}$ & $\begin{array}{c}\text { Cognitive, Affective } \\
\text { and Behavioral }\end{array}$ & 7 \\
\hline $\begin{array}{l}\text { Wilson et al., } \\
\mathbf{2 0 0 9}\end{array}$ & $\begin{array}{l}\text { Fantasy, Representation, Sensory Stimuli, Challenge, confusion Mystery, } \\
\text { Assessment and Control }\end{array}$ & $\begin{array}{l}\text { Cognitive, Affective } \\
\text { and Behavioral }\end{array}$ & 1 \\
\hline $\begin{array}{l}\text { Vogel et al., } \\
\mathbf{2 0 0 6}\end{array}$ & Fun, Participation, Interactions, , & Behavioral & 4 \\
\hline Aldrich, 2005 & Graphics, emotion, attitude & Affective & 3 \\
\hline
\end{tabular}


Table 2 shows that the game-based elements developed by the above scholars were adapted by all the 17 studies that were reviewed in this current study (see Table 3). The articles above were then further analyzed to identify the elements used to customize a game-based courseware. After identifying the elements that were incorporated in all the selected studies, the researcher compared the elements with five frameworks proposed by Alessi and Trollip, 2001; Prensky, 2013; Wilson et al., 2009; Vogel et al., 2006 and Aldrich, 2005. The 17 selected articles with empirical studies were then critically reviewed based on the following aspects, author, year of publication, game name, game type, game framework and game element, size effect and description of size effect (see Table 3).

Effect size is a simple way of quantifying the difference between two groups (Cohen, 1988). The effect size calculation is valuable for these studies because quantifying the effectiveness of these 17 articles' in game intervention will enable the researchers to identify relevant framework elements to adapt design courseware. Therefore, the studies adopted the below formula to calculate the effect size of each articles.

$$
\text { Cohen's } d=\frac{M_{1}-M_{2}}{S D_{\text {pooled }}}
$$

M1 = Mean of Treatment Group

M2= Mean of Control Group

$\mathrm{SD}=$ Standard deviation of two groups (SD1 + SD2)

Table 3 showed the values of estimated effect size to describe the effect of intervention in the 17 selected articles.
Table 3. Estimate Effect Size of Cohen's d

\begin{tabular}{|c|c|}
\hline Effect Size & Description of effect \\
\hline Cohen's d = less than.2 & small \\
\hline Cohen's d = is between .2 and.8 & medium \\
\hline Cohen's d = greater than .8 & large \\
\hline
\end{tabular}

Adapted: Cohen, J. (1988). Statistical Power Analysis for the Behavioral Sciences

\section{Results and Findings}

\subsection{Meta-Analysis of Digital Game-Based Learning for Mathematics'}

Table 4 represents the meta-analysis of Digital Game-Based Learning articles from year 2015-2018 in Mathematics' education. All selected articles adapted game-based elements from scholars as stated in Table 2 to customize the learning courseware. Table 4 shows the Meta-Analysis of Digital Game-Based Learning for Mathematics.

Table 3 shows that, in designing and developing game-based courseware, 7 studies adapted the Prensky (2001) framework, 2 studies adapted Alessi and Trollip, (2001), 3 studies used Aldrich, (2005), 1 study adapted Wilson et al., (2009) and 4 studies integrated Vogel et al., (2006). However, based on the articles reviewed, none of the studies incorporated all the game-elements developed by the respective scholars. The researchers claimed that it would be complex and complicated to integrate more than five domains of respective elements in a single game courseware. The adaptation of game elements by 17 researchers are recorded in Table 5. Table 5 demonstrates the details of game-based elements employed in the selected studies.

Table 4. Meta-Analysis of Digital Game Based Learning for Mathematics’

\begin{tabular}{|c|c|c|c|c|c|c|}
\hline Author & Game Name & Game Type & $\begin{array}{c}\text { Game } \\
\text { Framework }\end{array}$ & Game Elements & $\begin{array}{l}\text { Effect } \\
\text { Size }\end{array}$ & $\begin{array}{c}\text { Description of } \\
\text { Effect }\end{array}$ \\
\hline $\begin{array}{c}\text { Hamari et al., } \\
\text { (2016) }\end{array}$ & Quantun Spectre & $\begin{array}{l}\text { Serious } \\
\text { Game }\end{array}$ & Prensky, 2001 & $\begin{array}{l}\text { Challenge } \\
\text { Fun } \\
\text { adaptive } \\
\end{array}$ & 0.220 & Medium \\
\hline $\begin{array}{c}\text { Riemer \& } \\
\text { Schrader, (2015) }\end{array}$ & $\begin{array}{l}\text { Quiz, } \\
\text { Simulation, } \\
\text { Adventure }\end{array}$ & $\begin{array}{l}\text { Serious } \\
\text { Game }\end{array}$ & Prensky, 2001 & $\begin{array}{c}\text { Play } \\
\text { Goal } \\
\text { Enjoy } \\
\text { adaptive }\end{array}$ & 1.220 & Large \\
\hline $\begin{array}{c}\text { Jong, } \\
\text { Vandercruysse, } \\
\text { Wouters, } \\
\text { Oostendorp, \& } \\
\text { Elen, (2015) }\end{array}$ & $\begin{array}{c}\text { Competition and } \\
\text { Collaboration } \\
\text { game }\end{array}$ & $\begin{array}{l}\text { Computer } \\
\text { Game }\end{array}$ & $\begin{array}{c}\text { Alessi \& } \\
\text { Trollip, } 2001\end{array}$ & $\begin{array}{c}\text { Feedback } \\
\text { Multitasking } \\
\text { Conflict } \\
\text { Problem solving } \\
\text { Competition }\end{array}$ & 0.691 & Medium \\
\hline $\begin{array}{l}\text { Volk, Coti, Zajc, } \\
\text { \& Istenic, (2017) }\end{array}$ & $\begin{array}{c}\text { Cross Curricular } \\
\text { Maths }\end{array}$ & Video Game & Prensky, 2001 & $\begin{array}{c}\text { Outcomes } \\
\text { Problem Solving } \\
\text { Interaction } \\
\text { Enjoy } \\
\text { Feedback } \\
\end{array}$ & 0.250 & Medium \\
\hline $\begin{array}{l}\text { Kiili et al., } \\
\text { (2018) }\end{array}$ & $\begin{array}{l}\text { Rational Number } \\
\text { Training Games }\end{array}$ & $\begin{array}{c}\text { Educational } \\
\text { Game }\end{array}$ & $\begin{array}{l}\text { Wilson et al., } \\
2009\end{array}$ & $\begin{array}{c}\text { Play } \\
\text { Feedback } \\
\text { Reinforcement } \\
\text { Level } \\
\text { Problem Solving }\end{array}$ & 0.101 & Small \\
\hline
\end{tabular}




\begin{tabular}{|c|c|c|c|c|c|c|}
\hline $\begin{array}{l}\text { Jagu et al., } \\
\text { (2018) }\end{array}$ & Tablet Game & $\begin{array}{l}\text { Educational } \\
\text { Game }\end{array}$ & Aldrich, 2005 & $\begin{array}{l}\text { Graphic } \\
\text { Emotion } \\
\text { Attitude }\end{array}$ & 0.553 & Medium \\
\hline $\begin{array}{c}\text { Novak \& } \\
\text { Tassell, (2015) }\end{array}$ & Action Game & Video Game & Prensky, 2001 & $\begin{array}{c}\text { Problem Solving } \\
\text { Interaction } \\
\text { Feedback } \\
\text { Play } \\
\text { Win }\end{array}$ & 0.781 & Medium \\
\hline $\begin{array}{c}\text { Jong et al., } \\
\text { (2017) }\end{array}$ & Action Game & $\begin{array}{l}\text { Computer } \\
\text { Game }\end{array}$ & Prensky, 2001 & $\begin{array}{c}\text { Level } \\
\text { Goal } \\
\text { Interaction } \\
\text { Challenge } \\
\text { Representation } \\
\text { Adaptive } \\
\text { Rules } \\
\end{array}$ & 1.55 & Large \\
\hline $\begin{array}{l}\text { Mahmoudi, } \\
\text { Koushafar, } \\
\text { Amani, \& } \\
\text { Pashavi, (2015) }\end{array}$ & Action Game & $\begin{array}{l}\text { Computer } \\
\text { Game }\end{array}$ & $\begin{array}{l}\text { Vogel et al., } \\
2006\end{array}$ & $\begin{array}{c}\text { Fun } \\
\text { Problem Solving } \\
\text { Interaction }\end{array}$ & 0.553 & Medium \\
\hline $\begin{array}{c}\text { Baker, Martin, } \\
\text { \& Aghababyan, } \\
\text { (2015) }\end{array}$ & Fraction Game & $\begin{array}{l}\text { Educational } \\
\text { Game }\end{array}$ & Aldrich, 2005 & Graphic & 0.801 & Large \\
\hline $\begin{array}{l}\text { Mccarthy, Tiu, } \\
\text { \& Li, (2018) }\end{array}$ & $\begin{array}{l}\text { Narrative Based } \\
\text { Game }\end{array}$ & $\begin{array}{c}\text { Online } \\
\text { Video Game }\end{array}$ & $\begin{array}{l}\text { Wilson et al., } \\
2009\end{array}$ & $\begin{array}{c}\text { Winning } \\
\text { Interaction } \\
\text { Play } \\
\text { Representation } \\
\text { Problem Solving }\end{array}$ & 0.710 & Medium \\
\hline Fokides, (2018) & Kodu Game & $\begin{array}{l}\text { Digital } \\
\text { Game }\end{array}$ & $\begin{array}{l}\text { Vogel et al., } \\
2006\end{array}$ & $\begin{array}{c}\text { Fun } \\
\text { Participation }\end{array}$ & 0.236 & Medium \\
\hline García, (2017) & Algebra Game & $\begin{array}{l}\text { Computer } \\
\text { Game }\end{array}$ & $\begin{array}{l}\text { Vogel et al., } \\
2006\end{array}$ & $\begin{array}{c}\text { Fun } \\
\text { interaction } \\
\text { participation }\end{array}$ & 0.460 & Medium \\
\hline $\begin{array}{c}\text { Holgersson, } \\
\text { Barendregt, \& } \\
\text { Emanuelsson, } \\
\text { (2016) }\end{array}$ & $\begin{array}{l}\text { Virtual Finger } \\
\text { Game }\end{array}$ & $\begin{array}{l}\text { Computer } \\
\text { Game }\end{array}$ & Prensky, 2001 & $\begin{array}{l}\text { Interactive } \\
\text { Narrative } \\
\text { Goal } \\
\text { Feedback } \\
\text { Play } \\
\text { Winning } \\
\end{array}$ & 1.327 & Large \\
\hline $\begin{array}{c}\text { Yusoff et al., } \\
\text { (2017) }\end{array}$ & Maths Game & $\begin{array}{l}\text { Digital } \\
\text { Game }\end{array}$ & Prensky, 2001 & $\begin{array}{c}\text { Interactive } \\
\text { Narrative } \\
\text { Goal } \\
\text { Problem Solving } \\
\text { Play } \\
\text { Adaptive }\end{array}$ & 1.458 & Large \\
\hline $\begin{array}{l}\text { Tsia \& Yen, } \\
\text { (2016) }\end{array}$ & Fraction Game & $\begin{array}{l}\text { Digital } \\
\text { Game }\end{array}$ & Aldrich, 2005 & $\begin{array}{l}\text { Attitude } \\
\text { Graphic }\end{array}$ & 0.342 & Medium \\
\hline Venter, (2016) & Math Game & $\begin{array}{l}\text { Mobile } \\
\text { Game }\end{array}$ & $\begin{array}{c}\text { Alessi \& } \\
\text { Trollip, } 2001\end{array}$ & $\begin{array}{l}\text { Feedback } \\
\text { Strategy } \\
\text { Chance } \\
\text { conflict }\end{array}$ & 0.557 & Medium \\
\hline
\end{tabular}


Table 5. Descriptive Analysis of Game Based Elements in Learning Courseware

\begin{tabular}{|c|c|c|c|c|}
\hline $\begin{array}{l}\text { Engagement } \\
\text { Domain }\end{array}$ & Game Elements & Game Elements Description & $\begin{array}{l}\text { Number Of Articles } \\
\text { Related to Game } \\
\text { Elements(n) }\end{array}$ & $\begin{array}{l}\text { Percentage } \\
\text { (\%) }\end{array}$ \\
\hline \multirow{6}{*}{ Affective } & Attitude & commitment & 2 & 3.17 \\
\hline & Rules & Structure & 1 & 1.58 \\
\hline & Representation & Emotion & 4 & 6.35 \\
\hline & Win & Ego Gratifications & 3 & 4.76 \\
\hline & Emotion & Feeling & 1 & 1.58 \\
\hline & Interactive/graphic & Attention & 5 & 7.93 \\
\hline \multirow{5}{*}{ Cognitive } & Conflict/Challenge & Thinking & 4 & 6.35 \\
\hline & Adaptive & Flow & 4 & 6.35 \\
\hline & Problem Solving & Spark creativity & 7 & 11.11 \\
\hline & $\begin{array}{l}\text { Outcome/Feedback/ } \\
\text { reward/reinforcement }\end{array}$ & Learning & 8 & 12.69 \\
\hline & Multitasking & Various activities & 1 & 1.58 \\
\hline \multirow{4}{*}{ Behavioral } & Fun/enjoy & Enjoyment and Pleasure & 6 & 9.52 \\
\hline & Play & Intense involvement & 6 & 9.52 \\
\hline & Goal/Competition & Motivation & 5 & 7.93 \\
\hline & $\begin{array}{c}\text { Interact/ } \\
\text { collaboration }\end{array}$ & Social Groups & 6 & 9.52 \\
\hline
\end{tabular}

$\mathrm{n}=$ Number of articles

Table 5 provides an overview of the game elements, their description and percentage of studies that incorporate these elements that we found in the empirical studies. The data from this table are further discussed below. Based on Table 5, it is obvious that the 'outcome' element is the most used element compared to the rest. This element was adapted in 8 studies which correspond to $12.69 \%$. The outcome element refers to the statement that describes significant and essential learning that learners have achieved and can reliably demonstrate at the end of usage of learning courseware. The study conducted by García (2017) examined the effect of serious game on learners' training on task performances, engagement and knowledge. This study reflected a positive outcome after applying digital game-based learning approaches. The finding of this research also supported the notion that DGBL practices bring positive effect compared to non-gamified environment. Therefore, in games, the outcome element typically helps learners to distinguish the objective of learning, which further allows learners to accomplish the goal of the games (Volk, Coti, Zajc, \& Istenic, 2017). Apart from that, based on the outcome of the completed activities, learners can correct their mistakes (Furió et al., 2013). Thus, it reduces the misconception during problem-solving activities (Paris, 2017) . Therefore, the outcome element in game-based learning courseware is a crucial element to enhance learners' engagements in learning.

Next, the second most used game element is 'problem-solving'. This element was used in 7 articles out of 17 articles, which is equivalent to $11.11 \%$. According to García (2017), problem-solving is a form of thinking. The study of Yusoff et al., (2017) argued that the existence of problem-solving activities indirectly influences learners' interaction with their group of learning. (Baker et al., 2015) in his research, he found that both problem-solving and interaction correlated with each other in a way to maximize learners' understanding in Mathematics. Thus, the incorporation of problem-solving element in game-based learning enables learners to identify the problem and seek relevant methods to solve it. Many scholars argued that situating slow learners in a gamified environment eventually promote their problem-solving, engagement and motivation (Lim \& Leong, 2017). The research done by Fokides, (2018) compared two groups of students. Learners whom were taught with Kodu Maths learning coursewares showed a positive effect in solving problems with link to Mathmatics learning.

In addition, the findings also show that three elements, 'play', 'fun' and 'interact', recorded 9.52\% respectively. These three elements are in the behavorial engagement domain. Proponents stated that the play element in games enhances learners' participation in learning (Mantiri, 2014)(Coulthard, 2017). According to Mccarthy, Tiu, \& Li, (2018) the play element creates an intense and passionate involvement in learners to adapt games as a form of learning material and as a way to construct new knowledge. Holgersson, Barendregt, \& Emanuelsson, (2016) stated that embedding playful task in game-based learning fosters learners' creativity. Learners use their thinking ablity in order to complete activities like puzzles or quizzes. Novak \& Tassell, (2015) investigated that the relationship between the time of usage of game between two groups. The learners who play the game for 10 hours show significant improvement in memory and gemotery 
performances. Therefore, the play element assists learners to achieve the desired learning objectives.

The fun and interactive (5.73) elements considered one of the complex element in game based learning (Karimi \& Lim, 2010). Fun in learning gives a sense of enjoyment and pleasure (Tham, 2012). In order to create the enjoyment in learning, games should adapt high interactive attributes to retain learners' concentration in the games (Adamo-Villani \& Dib, 2013). Therefore, the interactive element in game-based learning is correlated with fun environment. The research conducted by Tsia \& Yen, (2016) stated that there is positive correlation with fun and interactive elements in their studies. Findings of the research show that learners seem to find the games easier to play and less frustrating because the instructions were easy to understand with the help of graphical animation. The graphical animation also makes the learning enjoyable. Thus, graphical animation engages learners in an effective way towards leaning. In addition, representation element in DGBL refers to story or narrative contents. Representation element in game-based learning offers a conceptual framework to structure game learning courseware. Games for learning are most effective when multiple sessions are involved, in other words, when users replay the game. The results indicate that the representation elements (fantasy stories) influence learners to immerse themselves in games. Indirectly, the representation element integration will lead to learners' contextual understanding.

Not only that, conflict in games create mood of excitement in learners to explore the games. Based on the studies above, it is noted that $4.35 \%$ of the selected articles (4) integrated conflict element in game-based learning. According to Vandercruysse et al., (2015) conflict in learning emerges when the players try to complete the assigned task to reach target goals. The research conducted by Jong et al., (2017) used faded worked examples in computer games. The findings of the research showed that effective integration of challenge element will improve the potential of players to accomplish the goal of the game.

Element such as rules, emotion and multitasking reported only $1.58 \%$, which were only adapted in one study to design and develop game-based learning. Win element creates ego gratification emotions, while multitasking elements is related to the challenge of doing various activities in order to master learning contents (Vogel, Greenwood-Ericksen, Cannon-Bowers, \& Bowers, 2006). Meanwhile, the rules elements possess different characteristics across various games. The rules in game generally constrain learners from being too intense and passionate in the games. Learners may feel that the rules in the game delay or decrease the chances of winning the game. However, Prensky (2001) stated that the rules element is a compulsory element to prevent players from cheating. For instance, without the rules, the students might use other electronic devices to complete the mathematical problems (Ortiz et al., 2015). Although certain game-elements such as rules, interactive, win/level/score are reported to have low percentage, the integration of these elements is equally important in designing a game-based learning courseware.

The findings revealed that most of the studies used Prensky's (2001) framework in their research to develop game courseware. They claimed that Prensky (2001) game elements are comprehensive in nature for the creation of educational materials, while simultaneously providing the most engaging educational experiences for students. It is also supported by the findings in this study, whereby 7 articles out of the 17 articles adapted Prensky's (2001) gaming elements to construct Mathematical learning courseware. Hence, based on the study conducted above, designers and developers should take Prensky (2001) into consideration when customizing learning courseware. In addition, it is clearly stated by Vygotsky (1978) that meaningful learning in the constructivism perspective enables learners to explore a content material in order to derive a new knowledge. Thus, DGBL Courseware in educational field should integrate game-based elements to promote learners' achievement and engagement in Mathematics education.

\section{Conclusions}

The discussion above detailed that the integration of relevant game-based elements can enhance learners' engagement in learning Mathematics. Failure in the integration of these elements in games in classroom settings would impact the learners' arithmetic skills acquisition. This study uncovers some essential information regarding relevant game-based elements frameworks that need to be in place in order to produce a highly impactful DGBL courseware.

\section{Acknowledgements}

The authors would like to thank Universiti Teknologi Malaysia and Ministry of Higher Education Malaysia for their support in making this project possible. This work was supported by the Fundamental Research Grant Scheme (R.J130000, 7831.4F932) initiated by Ministry of Higher Education.

\section{REFERENCES}

[1] Abdul Jabbar, A. I., \& Felicia, P. (2015). Gameplay Engagement and Learning in Game-Based Learning: A Systematic Review. Review of Educational Research, 85(4), 740-779. https://doi.org/10.3102/0034654315577210

[2] Adamo-Villani, N., \& Dib, H. (2013). Evaluating 
Technology-Based Educational Interventions: A Review of Two Projects. Journal of Educational Technology Systems, 41(4), 295-317. https://doi.org/10.2190/ET.41.4.b

[3] Aesaert, K., Van Nijlen, D., Vanderlinde, R., Tondeur, J., Devlieger, I., \& Van Braak, J. (2015). The contribution of pupil, classroom and school level characteristics to primary school pupils' ICT competences: A performance-based approach. Computers and Education, 87, 55-69. https://doi.org/10.1016/j.compedu.2015.03.014

[4] Alaswad, Z., \& Nadolny, L. (2015). Designing for Game-Based Learning: The Effective Integration of Technology to Support Learning. Journal of Educational Technology Systems, 43(4), 389-402. https://doi.org/10.1177/0047239515588164

[5] Alessi, S. \& Trollip, S. (2001). Multimedia for learning. New Jersey: Allyn and Bacon

[6] Aldrich, C. (2005). Learning by doing: A comprehensive guide to simulations, computer games, and pedagogy in e-learning and other educational experiences. San Francisco, CA: Pfeiffer.

[7] Baker, J. M., Martin, T., \& Aghababyan, A. (2015). Cortical Activations During a Computer-Based Fraction Learning Game: Preliminary Results from a Pilot Study. https://doi.org/10.1007/s10758-015-9251-y

[8] Bano, M., Zowghi, D., Kearney, M., Schuck, S., \& Aubusson, P. (2018). Mobile learning for science and mathematics school education: A systematic review of empirical evidence. Computers and Education, 121 (February 2017), 30-58.

https://doi.org/10.1016/j.compedu.2018.02.006

[9] Chauhan, S. (2017). A meta-analysis of the impact of technology on learning effectiveness of elementary students. Computers and Education, 105, 14-30. https://doi.org/10.1016/j.compedu.2016.11.005

[10] Coulthard, G. (2017). A Review of the Educational Use and Learning Impact of Simulations and Games Educational Use of Simulations and Games Running head: EDUCATIONAL USE OF SIMULATIONS AND GAMES A Review of the Educational Use and Learning Impact of Simulations and Games Glen, (June 2009).

[11] Dames, M. (2016). Exploring Changes In Computer Self-Efficacy During Graphics Skills Acquisition. Retrieved from http://scholarcommons.sc.edu/cgi/viewcontent.cgi?article= 4525\&context $=$ etd

[12] Fokides, E. (2018). Digital educational games and mathematics . Results of a case study in primary school settings, 851-867.

https://doi.org/10.1007/s10639-017-9639-5

[13] Fredricks., McColskey, W., Meli, J., Mordica, J., Montrosse, B., \& Mooney, K. (2011). Measuring student engagement in upper elementary through high school: A description of 21 instruments. Issues and Answers Report, (098), 26-27. Retrieved from http://ies.ed.gov/ncee/edlabs

[14] Freeman, S., Eddy, S. L., McDonough, M., Smith, M. K., Okoroafor, N., Jordt, H., \& Wenderoth, M. P. (2014). Active learning increases student performance in science, engineering, and mathematics. Proceedings of the National
Academy of Sciences, 111(23), 8410-8415.

[15] Furió, D., González-Gancedo, S., Juan, M. C., Seguí, I., \& Rando, N. (2013). Evaluation of learning outcomes using an educational iPhone game vs. traditional game. Computers and Education, 64, 1-23.

https://doi.org/10.1016/j.compedu.2012.12.001

[16] García, I. (2017). A computer game for teaching and learning algebra topics at undergraduate level, (July). https://doi.org/10.1002/cae.21887

[17] Hamari, J., Shernoff, D. J., Rowe, E., Coller, B., Asbell-clarke, J., \& Edwards, T. (2016). Computers in Human Behavior Challenging games help students learn: An empirical study on engagement, $\mathrm{fl}$ ow and immersion in game-based learning. Computers in Human Behavior, 54, 170-179. https://doi.org/10.1016/j.chb.2015.07.045

[18] Hirata, Y. (2018). E-learning courseware for language education in Japan: its application and student perceptions. Open Learning, 33(2), 83-98.

https://doi.org/10.1080/02680513.2018.1454833

[19] Holgersson, I., Barendregt, W., \& Emanuelsson, J. (2016). Fingu - A Game to Support Children's Development of Arithmetic Competence: Theory, Design and Empirical Research, 123-145.

https://doi.org/10.1007/978-3-319-32718-1

[20] Hussein, A. (2009). The use of Triangulation in Social Sciences Research: Can qualitative and quantitative methods be combined ?, 1-12.

[21] Hwang, G. J., Wu, P. H., \& Chen, C. C. (2012). An online game approach for improving students' learning performance in web-based problem-solving activities. Computers and Education, 59(4), 1246-1256. https://doi.org/10.1016/j.compedu.2012.05.009

[22] Jagu, T., Boti, I., \& So, H. (2018). Computers \& Education Examining competitive, collaborative and adaptive gami fi cation in young learners' math learning, 125(December 2017), 444-457.

https://doi.org/10.1016/j.compedu.2018.06.022

[23] Jong, T. De, Vandercruysse, S., Wouters, P., Oostendorp, H. Van, \& Elen, J. (2015). Computers \& Education How competition and heterogeneous collaboration interact in prevocational game-based mathematics education. Computers \& Education, 89, 42-52. https://doi.org/10.1016/j.compedu.2015.08.010

[24] Jong, T. De, Vandercruysse, S., Wouters, P., Oostendorp, H. Van, \& Elen, J. (2017). Computer game-based mathematics education: Embedded faded worked examples facilitate knowledge acquisition. Learning and Instruction, 50, 4453. https://doi.org/10.1016/j.learninstruc.2016.11.007

[25] Karajeh, W., Hamtini, T., \& Hamdi, M. (2016). Designing and implementing an effective Courseware for the Enhancement of e-learning. International Journal of Emerging Technologies in Learning, 11(4), 70-76. https://doi.org/10.3991/ijet.v11i04.5384

[26] Karimi, A., \& Lim, Y. P. (2010). Children, engagement and enjoyment in digital narrative. ASCILITE 2010 - The Australasian Society for Computers in Learning in Tertiary Education, (2001), 475-483. Retrieved from http://www.scopus.com/inward/record.url?eid=2-s2.0-848 
70734315\&partnerID=40\&md5=5ffbf45449733fbf 1 dce 39 $6462 \mathrm{fc} 3 \mathrm{~b} 75$

[27] Ke, F. (2013). Computer-game-based tutoring of mathematics. Computers and Education, 60(1), 448-457. https://doi.org/10.1016/j.compedu.2012.08.012

[28] Khamparia, A., \& Pandey, B. (2018). Effects of visual map embedded approach on students learning performance using Briggs-Myers learning style in word puzzle gaming course. Computers and Electrical Engineering, 66, 531-540. https://doi.org/10.1016/j.compeleceng.2017.12.041

[29] Kiili, K., Moeller, K., \& Ninaus, M. (2018). Computers \& Education Evaluating the e ff ectiveness of a game-based rational number training - In-game metrics as learning indicators. Computers \& Education, 120(February), 13-28. https://doi.org/10.1016/j.compedu.2018.01.012

[30] Kose, U., \& Arslan, A. (2015). Realizing an Optimization Approach Inspired from Piaget's Theory on Cognitive Development. BRAIN. Broad Research in Artificial Intelligence and Neuroscience, 6(1-2), 14-21. Retrieved from

https://www.edusoft.ro/brain/index.php/brain/article/view/ 483/553

[31] Kumar Bhowmik, M., Ping Lim, C., Smith, M., \& Victoria, L. T. (2018). 35 Digital Learning for Developing Asian Countries: Achieving equity, quality and efficiency in education. Abingdon: Routledge. Retrieved from http://www.oapen.org/record/648692

[32] Kwon, S., Lara, M., Enfield, J., \& Frick, T. (2013). Design and Evaluation of a Prompting Instrument to Support Learning within the Diffusion Simulation Game. Journal of Educational Technology Systems, 41(3), 231-253. https://doi.org/10.2190/ET.41.3.c

[33] Lim, K. C., \& Leong, K. E. (2017). A Study of gamification on GeoGebra for remedial pupils in primary mathematics. 21'st Asian Conference on Technologyin Mathematic, (December 2016), 8.

[34] Mahmoudi, H., Koushafar, M., Amani, J., \& Pashavi, G. (2015). The effect of computer games on speed , attention and consistency of learning mathematics among students, 176, 419-424. https://doi.org/10.1016/j.sbspro.2015.01.491

[35] Mantiri, F. (2014). Multimedia and Technology in Learning. Universal Journal of Educational Research, 2(9), 589-592. https://doi.org/10.13189/ujer.2014.020901

[36] Marvel, M. D. (2017). Player Characteristics and Games: Findings and Implications for Distance Learning. Journal of Educational Technology Systems, 46(2), 215-238. https://doi.org/10.1177/0047239517723138

[37] Mccarthy, E., Tiu, M., \& Li, L. (2018). Learning Math with Curious George and the Odd Squad: Transmedia in the Classroom. Technology, Knowledge and Learning. https://doi.org/10.1007/s10758-018-9361-4

[38] McLaren, B. M., Adams, D. M., Mayer, R. E., \& Forlizzi, J. (2017). A Computer-Based Game that Promotes Mathematics Learning More than a Conventional Approach. International Journal of Game-Based Learning, 7(1), 3656. https://doi.org/10.4018/IJGBL.2017010103

[39] Muppudathi, G. (2014). Role of Teachers on Helping Slow
Learners to Bring Out Their Hidden Skills. International Journal of Scientific Research, 3(3), 98-99.

[40] Murphy, C. A., Coover, D., \& Owen, S. V. (1989). Development and Validation of the Computer Self-Efficacy Scale. Educational and Psychological Measurement, 49(4), 893-899. https://doi.org/10.1177/001316448904900412

[41] Novak, E., \& Tassell, J. (2015). Computers in Human Behavior Using video game play to improve education-majors , mathematical performance: An experimental study. Computers in Human Behavior, 53, 124-130. https://doi.org/10.1016/j.chb.2015.07.001

[42] O’Connor, E. A., \& Domingo, J. (2017). A Practical Guide, With Theoretical Underpinnings, for Creating Effective Virtual Reality Learning Environments. Journal of Educational Technology Systems, 45(3), 343-364. https://doi.org/10.1177/0047239516673361

[43] Ortiz, S. A., Bowers, C. A., \& Cannon-Bowers, J. A. (2015). Video Game Self-efficacy and its Effect on Training Performance. International Journal of Serious Games, 2(3), 3-20. https://doi.org/10.17083/ijsg.v2i3.89

[44] Paris, E. (2017). Learning on Gaming : A New Digital Game Based Learning Approach to Improve Education Outcomes, (December). https://doi.org/10.17265/2161-623X/2017.09

[45] Pesare, E., Roselli, T., Corriero, N., \& Rossano, V. (2016). Game-based learning and Gamification to promote engagement and motivation in medical learning contexts. Smart Learning Environments. https://doi.org/10.1186/s40561-016-0028-0

[46] Prensky, M. (2001). Digital game-based learning. New York, NY: McGraw-Hill

[47] Riemer, V., \& Schrader, C. (2015). Computers \& Education Learning with quizzes, simulations, and adventures: Students ' attitudes , perceptions and intentions to learn with different types of serious games. Computers \& Education, 88, 160-168.

https://doi.org/10.1016/j.compedu.2015.05.003

[48] Rushton, S. J., Hadley, K. M., \& Stewart, P. W. (2016). MATHEMATICS FLUENCY AND TEACHING SELF-EFFICACY OF TEACHER CANDIDATES. Journal of the International Society for Teacher Education, 20(2).

[49] Schlesinger, Z., Wang, W. I., Heights, Y., \& Macdonald, A. H. (1987). '. $J$ V. https://doi.org/10.1007/978-3-540-92784 $-6$

[50] Teo, T., \& Koh, J. H. L. (2010). Assessing the Dimensionality of Computer Self-Efficacy among Pre-Service Teachers in Singapore: A Structural Equation Modeling Approach. International Journal of Education and Development Using Information and Communication Technology, 6(3), 7-18. https://doi.org/10.1097/QCO.0b013e32833de052

[51] Tham, L. T. and R. (2012). Is Game-Based Learning an Effective Instructional Strategy to Engage Students in Higher Education in Singapore? A Pilot Study. Journal of the Research Center for Educational Technology, 8, 12. Retrieved from http://rcetj.org/index.php/rcetj/article/view/160/261 
[52] Theses, R., Commons, N. M., Commons, S., Commons, T., Commons, D., \& Citation, R. (1998). Faculty computer self-efficacy and integration of electronic communication in teaching college courses.

[53] Tobias, S., Fletcher, J. D., \& Wind, A. P. (2014). Game-based learning. Handbook of Research on Educational Communications and Technology: Fourth Edition, (February), 485-503. https://doi.org/10.1007/978-1-4614-3185-5_38

[54] Tsai, F. H. (2018). The Development and Evaluation of a Computer-Simulated Science Inquiry Environment Using Gamified Elements. Journal of Educational Computing Research, 56(1), 3-22. https://doi.org/10.1177/0735633117705646

[55] Tsai, S. C. (2011). Courseware integration into task-based learning: A case study of multimedia courseware-supported oral presentations for non-English major students. ReCALL, 23(2), 117-134.

https://doi.org/10.1017/S0958344011000048

[56] Vasudevan, A. (2017). Slow Learners - Causes, Problems and Educational Programmes. International Journal of Applied Research, 3(12), 308-313.

[57] Venter, M. (2016). Continuance Use Intention of Primary School Learners Towards Mobile Mathematical Applications.

[58] Vogel, J. J., Greenwood-Ericksen, A., Cannon-Bowers, J., \& Bowers, C. A. (2006). Using virtual reality with and without gaming attributes for academic achievement. Journal of Research on Technology in Education, 39(1), 105-118. https://doi.org/10.1080/15391523.2006.10782475

[59] Volk, M., Coti, M., Zajc, M., \& Istenic, A. (2017). Computers \& Education Tablet-based cross-curricular maths vs . traditional maths classroom practice for higher-order learning outcomes, 114, 1-23. https://doi.org/10.1016/j.compedu.2017.06.004

[60] Wilson, K. A., Bedwell, W. L., Lazzara, E. H., Salas, E., Burke, C. S., Estock, J. L., Orvis, K. L., \& Conkey, C. (2009). Relationships between game attributes and learning outcomes: Review and research proposals. Simulation \& Gaming, 40(2), 217-266

[61] Yeh, Y.-T., Hung, H.-T., \& Hsu, Y.-J. (2017). Digital Game-Based Learning for Improving Students' Academic Achievement, Learning Motivation, and Willingness to Communicate in an English Course. 6th IIAI International Congress on Advanced Applied Informatics, 560-563. https://doi.org/10.1109/iiai-aai.2017.40

[62] Yusoff, S., Hoe, T. W., Zaffwan, M., Yusoff, S., Hoe, T. W., \& Zaffwan, M. (2017). Digital Game Based Learning: A New Method in Teaching and Learning Mathematics, 030016. https://doi.org/10.1063/1.4983894

[63] Zielezinski, M. B., \& Darling-Hammond, L. (2018). Advancing Equity Through Educational Technology: Promising Practices for Adoption, Integration, and Use in K-12. In J. Voogt, G. Knezek, R. Christensen, \& K.-W. Lai (Eds.), Second Handbook of Information Technology in Primary and Secondary Education (pp. 1-18). Cham: Springer International Publishing https://doi.org/10.1007/978-3-319-53803-7_95-1 